\title{
Structure and development of root gall induced by Meloidogyne javanica in Glycine max L.
}

\author{
Estrutura e desenvolvimento da galha radicular induzida por \\ Meloidogyne javanica em Glycine max L.
}

\author{
Roberta Mendes Isaac FerreiraVilela ${ }^{1 *}$; Vitor Campana Martini ${ }^{1}$; Letícia de \\ Almeida Gonçalves²; Vinícius Coelho Kuster ${ }^{3}$; Denis Coelho de Oliveira ${ }^{4}$
}

\begin{abstract}
Galls formed by root-knot nematodes have been studied in several cultivated species focusing on understanding the intimate relationship between parasite and the host plant. Species of Meloidogyne induce the development of a feeding site in the cortex or vascular cylinder of the host plant and are totally dependent on this site formation to complete their life cycle. Therefore, we focused on anatomical, cytological and histochemical changes during the establishment and development of galls and giant cells induced by Meloidogyne javanica in the roots of Glycine max. Seeds of soybean (susceptible cultivar M8372 IPRO) were sown in trays with coconut fibre substrate and the seedlings were removed ten days after the seeds emerged for nematode inoculation. The roots from inoculated and non-inoculated (control) were sampled at different stages of development until 55 days after inoculation. Histological, cytological, histochemical analysis were performed in light and electron microscopy in non-galled tissue and galls induced by M. javanica. The galls showed different shapes and abundance in the roots inoculated by M. javanica. The induction of galls occurs by hypertrophy of the root cortex shortly after the initial infection process. Giant cells were formed 18 days after nematode inoculation. These giant or nourishing cells are multinucleated, and have a dense cytoplasm, a thick wall with invaginations, many mitochondria and small vacuoles. The anatomical sections indicated a disorganisation of the cells of the cortex and vascular cylinder in relation to the control root.
\end{abstract}

Key words: Galls. Giant cells. Nematode. Root. Soybean.

\section{Resumo}

Galhas radiculares induzidas por nematoides têm sido estudadas em diversas espécies cultivadas, fornecendo subsídios para a compreensão da íntima relação entre parasita e hospedeiro. O estabelecimento do nematoide das galhas passa, necessariamente, pelo processo de formação das células gigantes, que garantem a nutrição do nematoide. As espécies de Meloidogyne estabelecem um sitio de alimentação no córtex ou cilindro vascular da raiz, sendo esses organismos totalmente dependentes deste sítio de indução. Desta forma o objetivo deste trabalho foi avaliar as alterações anatômicas, citológicas e

1 Discentes, Curso de Mestrado, Programa de Pós-Graduação em Biologia Vegetal, Universidade Federal de Uberlândia, UFU, Uberlândia, MG, Brasil. E-mail: robertaabtg@hotmail.com; vitorcmartini@gmail.com

2 Prof ${ }^{a}$ Dra $^{\mathrm{a}}$. Departamento de Botânica, Universidade Federal de Goiás, UFG, Goiânia, Go, Brasil. E-mail: leticia.icb.ufg@gmail. com

3 Prof. Ph.D. Unidade Especial de Ciências Biológicas, UFG, Campus Cidade Universitária, Jataí, GO, Brasil. E-mail: viniciuskuster@ufg.br

4 Prof. Dr. Curso de Pós-Graduação em Biologia Vegetal, Instituto de Biologia, UFU, Uberlândia, MG, Brasil. E-mail: oliveira.d.coelho@gmail.com

* Author for correspondence 
histoquímicas durante o desenvolvimento de galhas induzidas por Meloidogyne javanica em raízes de Glycine max. A variedade de soja utilizada foi a M8372 IPRO, susceptível ao nematoide M. javanica. As sementes foram semeadas em bandejas e depois colocadas em tubetes, onde foram realizadas coletas de amostras radiculares em diferentes estádios de desenvolvimento, tanto de plantas inoculadas com o nematoide quanto de plantas controle. As amostras de galhas e raízes não galhadas foram utilizadas para as análises histológicas, citológicas e histoquímicas, em microscopia óptica e eletrônica. Verificouse a presença de galhas após a inoculação de $M$. javanica, com variação na quantidade e na forma. A indução das galhas ocorre pela hipertrofia do córtex da raiz, logo após o processo inicial de infecção. Aos18 dias após a inoculação do nematoide já é possível observar a formação de células gigantes. Estas células gigantes ou nutridoras são multinucleadas, possuem citoplasma denso, parede espessa com invaginações, muitas mitocôndrias e pequenos vacúolos. As secções anatômicas indicaram uma desorganização das células do córtex e cilindro vascular em relação à raiz não inoculada (controle).

Palavras-chave: Galhas. Células gigantes. Nematoide. Soja.

\section{Introduction}

Galls are complex structures (MANI, 1964; RAMAN, 2007), whose development depends on the feeding action, physiology or mechanical damage caused by an inducing agent from distinct taxonomic groups (HORI, 1992). Root-knot nematodes cause abnormal radicular thickenings in which 1-10 sedentary female nematodes live (INOMOTO; SILVA, 2011). The nematodes induce changes in the host root anatomy by increasing cell division and hypertrophy (CARMO; SANTOS, 2008) and, especially, by forming giant cells (KRUSBERG; NIELSEN, 1958; SIDDIQUI; TAYLOR, 1970; JONES; DROPKIN, 1976; FINLEY, 1981). Galls are the true sink of nutrients competing with other host plant organs for resources produced in photosynthesis (CASTRO et al., 2012). In addition, the root-knot nematode can decrease the photosynthetic activity in leaves and consequently the yield and quality of the seeds produced (COSTA et al., 2003). Structural studies of root-knot nematodes in soybean are fundamental for the comprehension of the steps of gall and giant cells formation due to the importance of the soybean cropping and the need for nematode infestation control in this culture.

The gall-inducing process begins when root-knot nematodes penetrate into the root tissues. It usually occurs in the region of the root apex, where juvenile stage nematodes (J2) break through the root cell walls using both physical damage by stylet insertion and chemical degradation of the cell wall by cellulolytic and pectolytic enzymes. After multiple infections in a single root, the root tissue hypertrophy and root development cease temporarily. Then, J2 migrates through cortex cells in the region of cell differentiation, causing the destruction of the middle lamella, and subsequently move towards the vascular cylinder where they become immobile (KARSSEN; MOENS, 2006). In the vascular cylinder, the rootknot nematodes induce the formation of giant cells that show a dense and granular cytoplasm with several conspicuous nuclei (FAVERY et al., 2016). They therefore go from the juvenile to the sausageshaped stage, lose their mobility and start feeding on the development of giant cells in the root, where parasitism occurs (FERRAZ; MONTEIRO, 1995). In fact, the development of giant cells, also known as feeding cells, is fundamental to establishment of the nematode life cycle in host plants (TAYLOR; SASSER, 1978). Giant cell formation and parenchyma cell hypertrophy cause the obliteration of xylem vessel elements and the total disruption of the vascular system (WANDERLEY; SANTOS, 2004). Thus, this process has major impacts on the absorption of water and, consequently, soil nutrients, which predisposes the plant to environmental stresses (WHITEHEAD, 1997).

Plants have developed a number of defence mechanisms in order to resist parasite attack. Such mechanisms involve alterations in the metabolism of hormones and phenolic compounds and in the defence regulators, the production of toxic substances, and the modification of plant tissue structure (FARIA et al., 2003; MAFFEI et al., 
2007). Thus, histochemical methods can provide a wide range of chemical and physiological answers in relation to structural modification induced by root-knot nematode on host plant. In addition, histopathological studies are especially interested in the interactions with Meloidogyne species, which are good models for the study of the gall-inducing process and giant cell formation. This is because the development of these cells is still not well understood due to their complexity, which involves host and nematode plant genes. Here, we focus on the Meloidogyne javanica-Glycine max interaction with the aim of analysing the morphological and anatomical development of galls, describing the ultrastructural impact caused by the root-knot nematode on the root tissues, especially during giant cell formation, and evaluating the biotic stress caused by the parasite on the gall tissues from a histochemical perspective.

\section{Material and Methods}

\section{Experiment settings}

The experiment took place in the greenhouse of Goiatuba University Center (Unicerrado), municipality of Goiatuba, Goiás state, Brazil. The greenhouse temperature was maintained at $32^{\circ} \mathrm{C}$ and a humidity of $80 \%$. The soybean cultivar was as M8372 IPRO ${ }^{\circledR}$, which is susceptible to Meloidogyne javanica. The seeds of Glycine max (soybean) were sown in trays with coconut fibre substrate, Biomassa ${ }^{\circledR}$. For the inoculation procedure, we removed the seedlings from the substrate, and, ten days after seed germination, put them into tubes containing sterilised soil in a 7:1 sand/soil proportion. Next, we used a $5 \mathrm{~mL}$ pipette with $2000 \mathrm{~J} 2$ stage individuals of $M$. javanica to inoculate each plant. Fifty plants were inoculated and 50 individuals were kept noninoculated as the control group.

After 15 days of inoculation, $10 \mathrm{ml}$ of Hoagland nutrient solution (TUITE, 1969) compound was used in each tube just for one time. Samples from inoculated and non-inoculated groups were evaluated at $4,11,18,25,32,39$ and 45 days after inoculation (DAI inoculation). At 55 DAI, the galls were isolated, counted and weighed in an analytical balance for the Gall Index (GI) evaluation, as proposed by Taylor and Sasses (1978).

\section{Structural analysis}

The roots from medial and apical regions, from inoculated and non-inoculated groups, were fixed in FAA 50 solution (formaldehyde + acetic acid + $50 \%$ ethanol, 1:1:18) for light microscopy analysis (JOHANSEN, 1940), and in Karnovsky's fixative solution for transmission electron microscopy (TEM) (KARNOVSKY, 1965). The samples were dehydrated in ethanolic series $(50,70,80,90$ and $100 \%$ ) and, afterwards, embedded in Historesin, Leica $^{\circledR}$. Transverse sections of both groups of samples were made in a rotary microtome and stained with toluidine blue (FEDER; O'BRIEN et al., 1968) in phosphate buffer, $\mathrm{pH}$ 5.9. For the visualisation of lignin, sections of the handmade cuts were photographed using the DAPI filter, at 55 days.

For the TEM analysis, we post-fixed the samples in $1 \%$ osmium tetroxide in a phosphate buffer solution (0.1 M, pH 7.2), dehydrated through ethanolic series (O'BRIEN; McCULLY, 1981) and gradually embedded in resin, Spurr ${ }^{\circledR}$. The blocks were cut into sections using a diamond knife on a Reichert-Jung Ultracut ultramicrotome (Leica, Wetzlar, Germany), fixed in nets and contrasted with uranyl acetate and lead citrate (REYNOLDS, 1963). Then, we performed their analysis in a transmission electron microscope (Jeol, JEM-2100) equipped with EDS (energy dispersive x-ray detector), at Laboratory of High Resolution

Microscopy (LabMic), Federal University of Goias, Brazil.

\section{Histochemical analysis}

The newly collected samples of fresh material were cut by hand at 55 DAI and then underwent different histochemical tests (Table 1). 
Table 1. Histochemical tests used in the interaction of M. javanica/G. max, groups of metabolites and methodologies.

\begin{tabular}{|c|c|c|}
\hline $\begin{array}{l}\text { REAGENT TEST / } \\
\text { SUBSTANCES }\end{array}$ & PROCEDURE & REFERENCES \\
\hline $\begin{array}{l}\text { Reagent Lugol/ } \\
\text { CARBOHYDRATES (Starch) }\end{array}$ & $\begin{array}{l}\text { Immersion of the samples into } 1 \% \text { iodinated potassium } \\
\text { iodide for } 5 \text { minutes. }\end{array}$ & Jensen (1962) \\
\hline $\begin{array}{l}\text { Reagent Fehling /REDUCING } \\
\text { CARBOHYDRATES }\end{array}$ & $\begin{array}{l}\text { Immersion of the samples in equal parts of "A" ( } 6.93 \% \mathrm{~m} \text { : } \\
\text { v) and "B" ( } 2 \% \text { potassium sulphate) }(34.6 \% \text { sodium and } \\
\text { potassium tartrate and } 12 \% \text { sodium hydroxide: m: v: ) heated } \\
\text { to pre - boiling. }\end{array}$ & Sass (1951) \\
\hline $\begin{array}{l}\text { Reagent Ruthenium red / } \\
\text { CARBOHYDRATES (Pectins) }\end{array}$ & $\begin{array}{l}\text { The sections were immersed in a solution of Ruthenium Red } \\
\text { at } 1000 \mathrm{ppm} \text { for } 10 \text { minutes, and then washed in distilled } \\
\text { water. }\end{array}$ & $\begin{array}{l}\text { Johansen } \\
(1940)\end{array}$ \\
\hline $\begin{array}{l}\text { Reagent Bromophenol mercury } \\
\text { blue /PROTEINS }\end{array}$ & $\begin{array}{l}\text { Immersion of the samples in } 0.1 \% \text { bromophenol blue in a } \\
\text { saturated solution of magnesium chloride in } 70 \% \text { alcohol for } \\
15 \text { minutes. }\end{array}$ & $\begin{array}{l}\text { Mazia et al. } \\
(1953)\end{array}$ \\
\hline $\begin{array}{l}\text { Reagent Vermelho B Sudão IV/ } \\
\text { LIPIDS (General lipid) }\end{array}$ & $\begin{array}{l}\text { The sections were immersed in a saturated solution of } \\
\text { Scarlet Red }( \pm 0.3 \%) \text { in } 70 \% \text { ethanol for } 15 \text { minutes at room } \\
\text { temperature environment and then washed rapidly with } 70 \% \\
\text { ethanol and water distilled. }\end{array}$ & Pearse (1980) \\
\hline $\begin{array}{l}\text { Reagent Iron Chloride III/ } \\
\text { PHENOLICS (General phenolic) }\end{array}$ & $\begin{array}{l}\text { The cuts were immersed in the } 10 \% \text { iron chloride III } \\
\text { solution for } 15 \text { minutes and then washed in distilled water. }\end{array}$ & $\begin{array}{l}\text { Johansen } \\
(1940)\end{array}$ \\
\hline $\begin{array}{l}\text { Reagent DAB/REACTIVE } \\
\text { OXIGEN SPECIES }\end{array}$ & $\begin{array}{l}\text { Dip the samples into 3,3'-diaminobenzidine for } 20 \text { minutes } \\
\text { in the dark under refrigeration. Quick wash and assemble in } \\
\text { distilled water. }\end{array}$ & $\begin{array}{l}\text { Rossetti and } \\
\text { Bonatti (2001) }\end{array}$ \\
\hline
\end{tabular}

\section{Results}

\section{Structural profile of Meloidogyne javanica-Glycine max system}

The control plants (Figure 1A) had a typically primary anatomy, with a uniseriate epidermis, a cortical parenchymal showing large cells with large intercellular spaces, and a protostelic and tetrarch vascular cylinder (Figure 1B-C).

The galls induced by $M$. javanica on G. max stood out external to the root and were disposed both individually or clustered (Figure 1A), showing an irregular shape (Figure 1A). There was no noticeable difference between the external morphology of inoculated and control plants at 4 DAI (Figure 2AB). Galls started to be noted at around 11 DAI, when the gall sites in the roots started to thicken (Figure 2C) and became obvious at 18 DAI. At 25 DAI, the galls were more numerous and evident (Figure 2D-G). They were usually globe-shaped, with variations in size and form (Figure $2 \mathrm{C}-\mathrm{G}$ ). At 55 DAI, the fresh mass of the galls was $0.15 \mathrm{~g}$ and gall abundance varied from 13 to 202, with an average of 50 galls per plant, putting the plant in degree 4 of susceptibility according to the scale of Taylor and Sasser (1978). 
Figure 1. Morphological and anatomical characteristics of soybean inoculated and not inoculated with Meloidogyne javanica. (A) Root and shoot. Detail of the root with galls in groups or individually. Detail of a hive. (B) Anatomy of the root of the control plant at 18 days, showing epidermis, parenchymal cortex and tetrarch vascular cylinder. (C) Detail of the vascular cylinder showing the metaxylem, protoxylem and phloem of the control plant at 55 days. Legend: $\mathrm{Co}=$ Cortex, En $=$ Endodermis, $\mathrm{Gga}=$ Group of Galls, Iga $=$ Individual Galls, Met $=$ Metaxylem, $\mathrm{Ph}=$ Phloem, Pro $=$ Protoxylem, $\mathrm{RN}=$ Radical nodules by bacteria, $\mathrm{VC}=$ Vascular Cylinder .

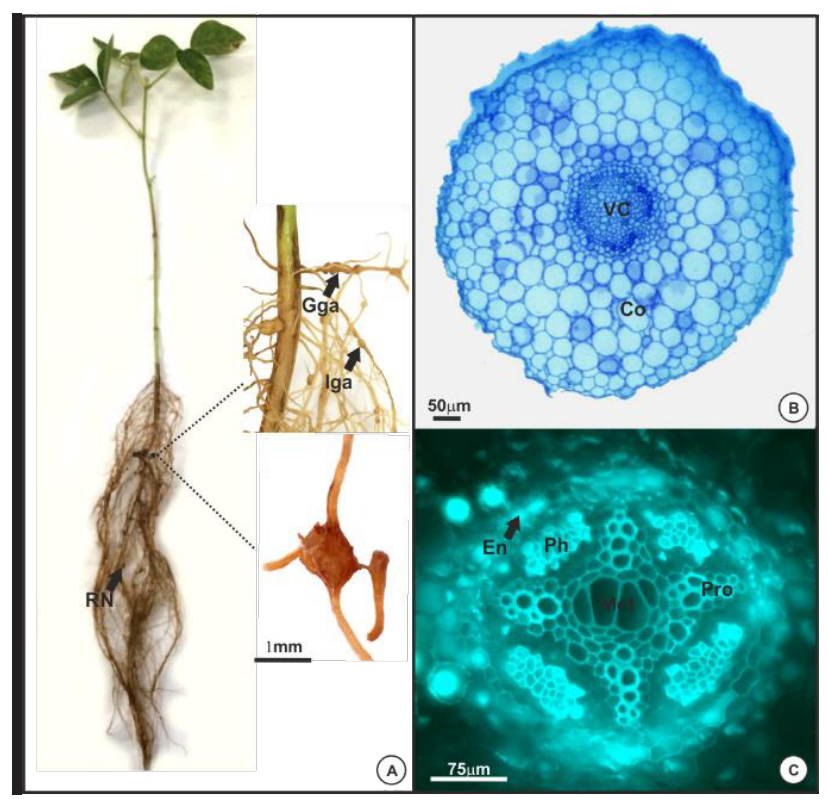

Figure 2. Aspect of the soybean roots without and with the inoculation of Meloidogyne javanica. (A) Not inoculated (control). (B) After four days of inoculation, absence of galls. (C) After 11 days of inoculation, slight thickening. (D-E-F-G) Galls at different stages of development, with varying shapes and sizes. Bar: $0.5 \mathrm{~mm}$. Legend: Ga $=\mathrm{Knot}$ or Gall, LR = Lateral Root.

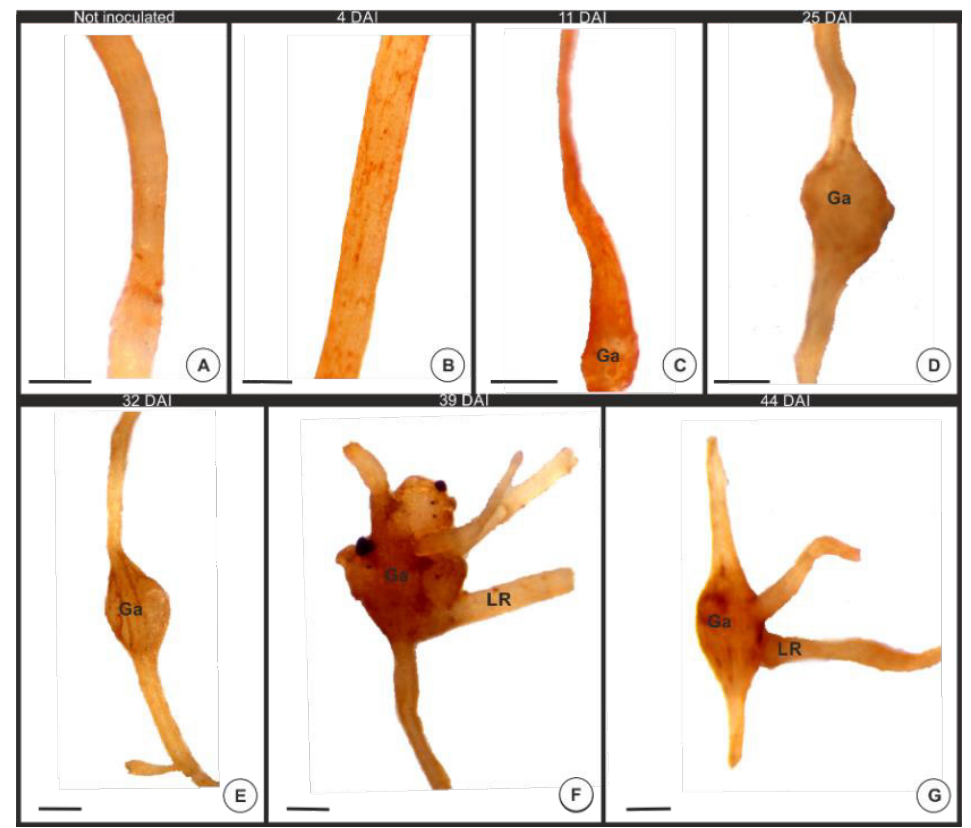


There were no anatomical alterations in the roots of G. $\max$ at 4 and 11 DAI (Figure 3A). After that, at 18 DAI, giant cells started to develop (Figure 3BC), showing a typical susceptibility reaction with cell alterations such as dense granular cytoplasm and thicker cell walls. At 25 DAI, vascular cylinders were anatomically disorganised, giant cells were completely differentiated (Figure 3D-E), and female nematodes were conspicuous (Figure 3.F). At 32 and 39 DAI, the giant cells were bigger and multinucleated (Figure 4A). After that, the female nematodes could be seen to make contact with the feeding site from 39 to 44 DAI (Figure 4.B-C).

Figure 3. Transverse cuts of soybean roots inoculated with Meloidogyne javanica. (A) At 4 (DAI) a root without the formation of giant cells. (B-C) After 18 (DAI), formation of giant cells with a dense and multinucleated cytoplasm. (D-F) At 25 (DAI), showing two giant cells and the formation of others, also showing a cross-sectional nematode female. Bar: A - F $=50 \mu \mathrm{m}$. Legend: $\mathrm{Co}=$ Cortex, $\mathrm{DC}=$ Dense Cytoplasm, $\mathrm{GC}=$ Giant Cell, LC $=$ Larval Chamber, $\mathrm{Ne}=$ Nematode, $\mathrm{Nu}=$ Nucleus, $\mathrm{VC}=$ Vascular Cylinder.

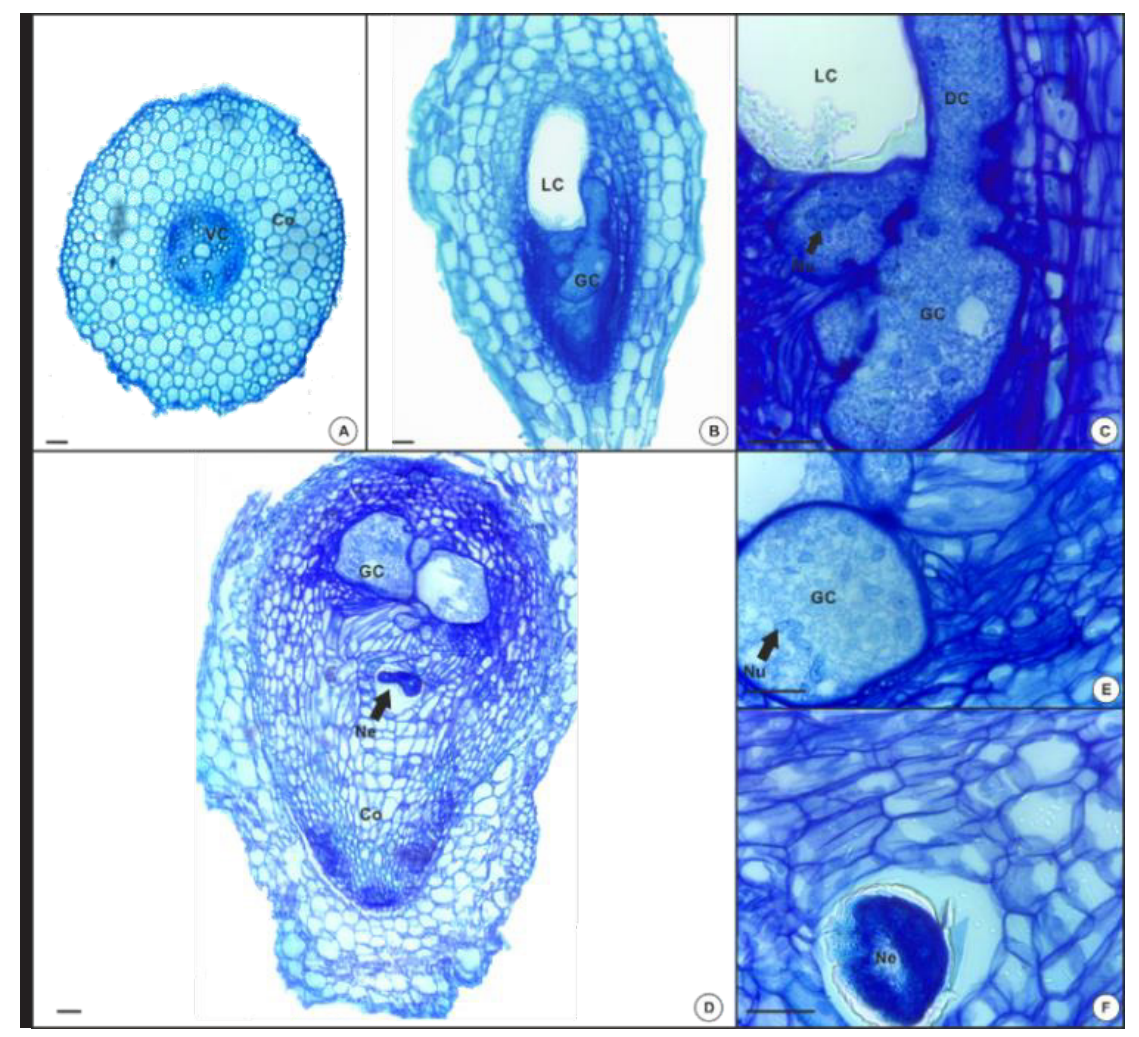


Figure 4. Cross cuttings of soybean roots inoculated with M. javanica. (A) At 32 (DAI), 5 well-developed giant cells, and a severe disorganisation of the vascular cylinder; in detail, the giant cells show thick walls and several nuclei. (B-C) Female of the nematode in contact with the feeding site. Bar: A - C $=50 \mu \mathrm{m}$. Legend: GC $=$ Giant Cell, $\mathrm{LC}=$ Larval Chamber, $\mathrm{LR}=$ Lateral Root, $\mathrm{Ne}=$ Nematode, $\mathrm{Nu}=$ Nucleus, $\mathrm{Ph}=$ Phloem, $\mathrm{Xy}=\mathrm{Xylem}$.

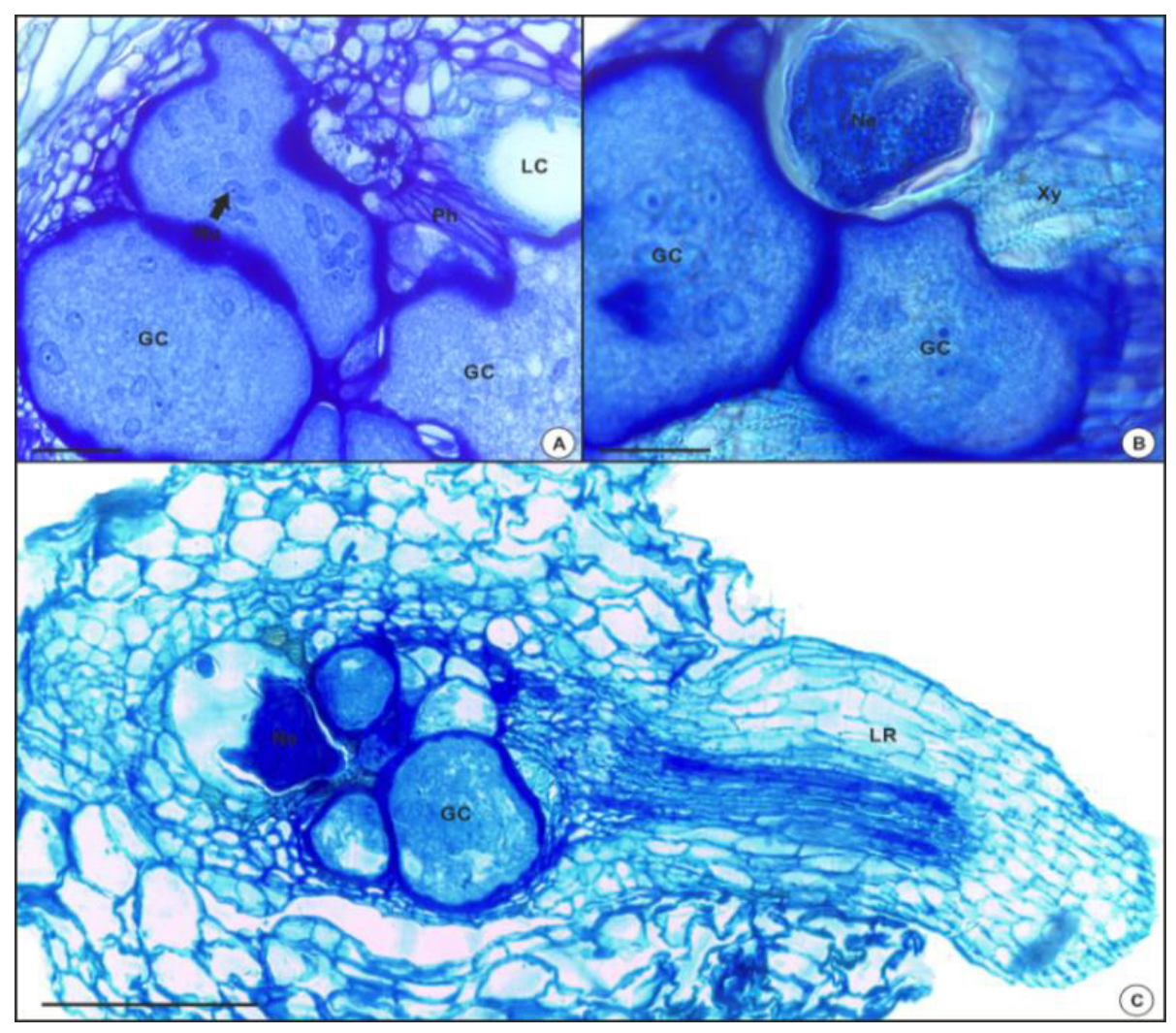

In non-inoculated roots, the cortex was filled with parenchymal cells with thin walls and parietal cytoplasm (Figure 5A-C). Giant cells showed an abundance of organelles, with a large number of plastids (Figure 4D) and mitochondria (Figure 5D-E), which become much more abundant in such cells. The vacuole fragmentation is also noticeable (Figure 5F-G), as is the proliferation of the endoplasmic reticulum and the Golgi apparatus (Figure 5J). In some giant cells, the walls invaginate to the inner cell (Figure 5I), which is very similar to that typical of transference cells. 
Figure 5. Electromicrographs of cells present in the soybean root not inoculated and inoculated with Meloidogyne javanica. (A-C) Cells from uninoculated roots. (A) Parenchymal cells of the control cortex showing thin walls. (B) Vascular cylinder with xylem vessel element detail. (C) Detail of a typical cortex cell showing parental cytoplasm. (DJ). Giant cells of inoculated roots. (D) Amyloplasts, dense cytoplasm and mitochondria. (E) Detail of mitochondria. (F) Fragmented vacuole. (G) Detail of the vacuoles, amyloplast and mitochondria. (H) Nucleus with ameboid and nucleolus evident format. (I) Labyrinthic cellular wall. (J) Dictiosomes. Legend: $\mathrm{Cy}=$ Cytoplasm, CW $=$ Cell Wall, $\mathrm{ER}=$ Endoplasmic Reticulum, $\mathrm{GC}=$ Giant Cell, $\mathrm{GCo}=$ Golgi Complex, $\mathrm{In}=$ Invagination, $\mathrm{Mi}=$ Mitochondria, $\mathrm{Nu}=$ Nucleus, Nuc $=$ Nucleolus, $\mathrm{Pa}=$ Parenchyma, $\mathrm{St}=\mathrm{Starch}, \mathrm{SW}=$ Secondary Wall, $\mathrm{Va}=$ Vacuole, $\mathrm{VE}=$ Vessel Element, $\mathrm{WI}=$ Wall with invaginations.

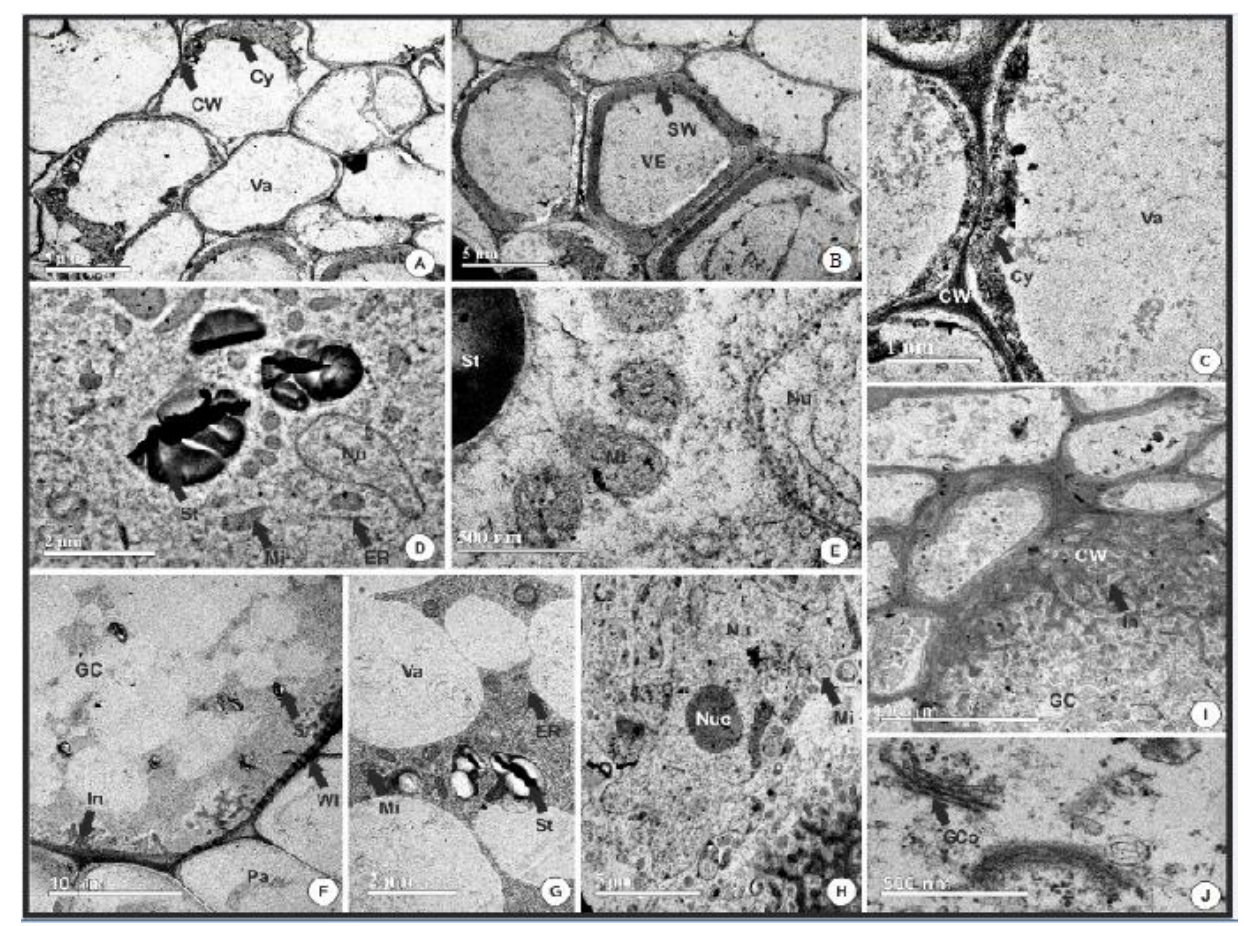

\section{Histochemical analysis}

The histochemical tests (Table 2) performed in inoculated and control roots showed that noninoculated roots presented a regular distribution of starch (Figure 6A-B), while parasitised roots had a major concentration of starch granules in the vascular cylinder and around giant cells (Figure 6E-
F). In control roots, the amount of reactive oxygen species (ROS) was greater in the cortex than in the vascular cylinder (Figure 6C- D). Small amounts of lipid droplets were detected dispersed in the inoculated roots and in nematodes (Figure 6H-I). Phenolic compounds, flavonoids and pectins were not detected in either control or inoculated plants. 
Table 2. Histochemical tests used in the interaction of $M$. javanica/Glycine max for the presence and absence of metabolites.

\begin{tabular}{lccc}
\hline SUBSTANCES & & CONTROL & INOCULATED \\
\hline CARBOHYDRATES & (starch) & + & + \\
$\mathrm{J}$ & (reducing carbohydrates) & - & - \\
& (pectins) & - & - \\
PROTEINS & (total proteins) & + & + \\
PHENOLICS & (general phenolic) & - & - \\
& (flavonoids) & - & - \\
LIPIDS & (general lipid) & - & + \\
REACTIVE OXIGEN SPECIES & (ROS) & + & + \\
\hline
\end{tabular}

Abbreviations: (-) negative reaction; (+) positive reaction.

Figure 6. Histochemical analyses of inoculated soybean roots and control after 55 days (DAI) with M. javanica. (A-B) Control root, starch granules in the vascular cylinder, and detail of starch granules in the cortex. (C) Vascular root canal cylinder, ROS. (D). Inoculated root, ROS. (E-F) Inoculated root, starch granules in the vascular cylinder. (G) Inoculated root, proteins. (H). Inoculated, lipid droplets. (H-I) Inoculated root, presence of lipid droplets in the nematode and nearby regions. $(\mathrm{J})$ Inoculated, ROS. Legend: $\mathrm{Co}=$ Cortex, $\mathrm{Fi}=$ Fibre, $\mathrm{GC}=$ Giant Cell, $\mathrm{LC}=\mathrm{Larval}$ Chamber, $\mathrm{LD}=$ Lipid Droplet, $\mathrm{Li}=$ Lipid, $\mathrm{Ne}=$ Nematode, $\mathrm{Pa}=$ Parenchyma, $\mathrm{Ph}=\mathrm{Phloem}, \mathrm{Pr}=$ Protein, $\mathrm{St}=\mathrm{Starch}$, $\mathrm{VE}=$ Vessel Element.

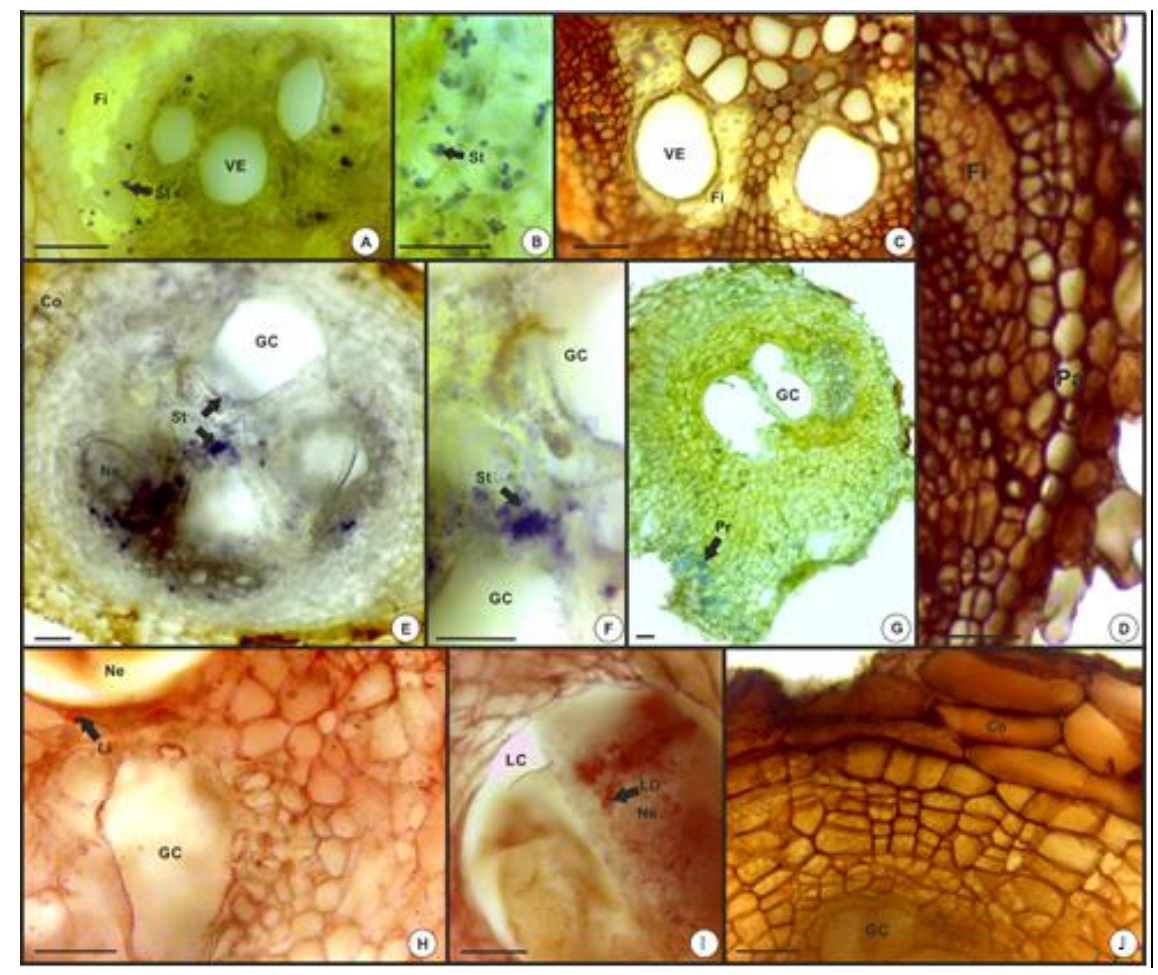




\section{Discussion}

The roots of G. max are attacked by the phytopathogenic root-knot nematodes, which are able to induce galls in many cultivars. After $M$. javanica (root-knot nematode) infects the soybean, the roots show hypertrophy of their cells of the cortex, which results in gall formation, and the differentiation of cells of the vascular cylinder into giant cells. The initial trigger for giant cell formation comes from secretions of the oesophageal glands of the nematodes (FERRAZ, 2001). These secretions play a key role in the parasitic relationship with plants (REHMAN et al., 2016), altering the cell cycle of the host plant and leading to innumerous nuclear divisions, lacking the cytokinesis process, as observed in the gall induced by M. javanica on soybean. Giant cells are essential to the development and reproduction of the nematode (KINDTet al., 2016); however, gall development, especially from parenchyma cell hypertrophy, is considered to be a good indicator of infection (FERRAZ, 2001), and is not fundamental to the success of the root-knot nematode.

Galls induced by $M$. javanica are conspicuous in soybean roots, as also observed by Ferraz and Brown (2016), in beans, pumpkins, cucumbers, okra, tomatoes, tobaccos and peaches, all of which present numerous galls of large dimensions. The variation in gall sizes and shapes was easily noticed; such a discrepancy depends on the Meloidogyne species, on the infection degree observed and on the host plant involved (FERRAZ, 2001). In contrast, maize and sorghum roots parasitised by Meloidogyne present few evident galls, which appear as light thickenings, hindering their identification in the field (ASMUS et al., 2000). In some cases, gall formation cannot occur, or is greater in response to the attack of multiple nematodes in a single induction site. Although it is not a rule, a correlation between the size of the infested plant root system and the rate of nematode multiplication might exist (HUSSEY; JANSSEN, 2002).
The galls can be detected on roots of soybean at 11 DAI, although giant cell differentiation did not take place. In a study of galls induced by $M$. javanica in rubber trees, giant cells were found in the vascular cylinder at 20 DAI (FONSECA et al., 2003). Here, galls induced by $M$. javanica showed giant cells at $18 \mathrm{DAI}$, similar that found by Westerich et al. (2012), where giant cells were found in galls induced by $M$. enterolobii on roots of tomatoes after 17 DAI. In general, giant cells are formed between 18 and 20 DAI, regardless of the host species or the inducer Meloidogyne species. Giant cell formation is partially controlled by the reorganisation of the cytoskeletons from the vascular cylinder cells and, consequently, by the reorganisation of cellulose microfibrils inside the cell wall (ALMEIDA ENGLER et al., 2004). Such reorganisation allows the hypertrophy of cells, thus forming giant cells (FAVERY et al., 2016).

Herein, we showed that the formation of giant cells occurs at 18 DAI and disorganises the vascular system in the induction site, which could lead to total or partial suppression of the protoxylem poles. These mechanical alterations in the root systems of plants attacked by Meloidogyne spp. are irreversible and at least partially responsible for the severe damage caused by such nematodes (KINDT et al., 2016; FAVERY et al., 2016). At 32 DAI, more giant cells could be observed. These cells were multinucleate, with the nuclei of either amoeboid or lobed forms, as already found by Fonseca et al. (2003), in rubber trees infected by M.javanica and M. exigua. Studies of sweet potato roots parasitised by Meloidogyne showed that giant cells have nuclei with varied shapes and sizes; the nuclei are sometimes up to 100 times larger than those of neighbouring cells (KRUSBERG; NIELSEN, 1958).

In addition to the multinucleate condition of giant cells, there is a large number of mitochondria, mostly close to the invaginated cell walls, which corroborates the results found by Gunning (1977), in giant cells induced by $M$. exigua. The presence 
of these mitochondria indicates periods with the greater entrance of organic solutes and other elements into giant cells. Mitochondria vary in size and shape, depending on their origin and metabolic state (VOET et al., 2002), and they are one of the most important organelles, as they produce reactive oxygen species (ROS) and are responsible for generating most of the free radicals seen in animal cells and non-photosynthetic plant tissues, according to Galina (2006). Klessig et al. (2000) stated that ROS play an important role in plant defence during pathogen attack and, in addition, can trigger gall development (OLIVEIRA et al., 2014). Herein, we detected the presence of ROS molecules $\left(\mathrm{H}_{2} \mathrm{O}_{2}\right)$ by DAB test especially in the cell walls of hypertrophied cells of nematode galls. These molecules can develop a key role in the processes of cell wall loosening and consequently cell growth, elongation and hypertrophy (DEL RÍO; PUPPO, 2009). In general, the $\mathrm{H}_{2} \mathrm{O}_{2}$ molecules in the cell wall are broken by the Haber-Weiss reaction to form $\mathrm{OH} \bullet$ (hydroxyl radical). These molecules of hydroxyl radical cleave the cell wall polysaccharides, leading to wall loosening (KAWANO, 2003). In addition, the processes of cell elongation induced by IAA (indole-3-acetic acid) are dependent of ROS production that cleave the cell wall polymers for consequent cell growth (LISZKAY et al., 2004). The presence of IAAs associated with ROS have already been detected in galls and were associated to cell hypertrophy (BEDETTI et al., 2014).

We also noted the proliferation of the Golgi apparatus, plastids, ribosomes and endoplasmic reticulum in the giant cells, as previously reported by Vieira et al. (2013), Berg et al. (2008), Sobczak and Golinowski (2011). In the induced giant cells, single large central vacuoles were replaced with several smaller ones, as reported by Bird (1961), Davis et al. (2004) and Abad et al. (2009), by Westerich et al. (2012) in tomato roots inoculated with M. enterolobii, and by Fonseca et al. (2003) in rubber trees infected by $M$. javanica. The induction and maintenance of giant cells depend on continuous stimuli from the nematodes, without which the cells atrophy. Thus, giant cells are usually formed close to the anterior regions of nematodes, as seen in the present study, or around the site of mouth stylet insertion (REDDIGARI et al., 1985).

Some of the giant cells found in G. $\max$ presented modifications in their walls, containing invaginations turned to the cell lumen. Such results were also reported by some authors, like Berg et al. (2008), Sobczak and Golinowski (2011), and Vieira et al. (2013). These invaginations and protuberances in the walls are responsible for increasing the membrane surface area for greater solute absorption (GOLINOWSKI et al., 1996; HUSSEY; GRUNDLER, 1998), thus favouring nematode nourishment. According to Berg et al. (2008), giant cell walls with labyrinthine thickenings raise the flow of substances between feeding cells (JONES; NORTHCOTE, 1972; JONES; GUNNING, 1976). The solutes derived from the phloem are "symplastically" imported to giant cells through the plasmodesma (VIEIRA et al., 2013; HOFMANN et al., 2010; VIEIRA et al., 2012) or by active transport (apoplast), which justifies the greater amount of mitochondria close to the wall. A thicker cell wall, a dense and sometimes granular cytoplasm and the presence of plastids were also found by Westerich (2010) at the feeding sites of Meloidogyne mayaguensis in "Magnet" and "Helper M" tomato plants. In response to the chemical action of the enzymes secreted by Meloidogyne species, a continuous cell division process occurs, but without the cytoplasmic division (ENDO, 1987), thus forming larger cells with thicker walls, high metabolic activity and a dense cytoplasm (JONES, 1981; HUSSEY; WILLIAMSON, 1998).

Plants react to gall-inducing nematode attacks using defence mechanisms that are usually complex and based on the combined action of several factors (FARIA et al., 2003). For example, the accumulation of phenolic compounds in the cortex and vascular parenchymal cells suggest that they act in defence of the plants facing the nematode attacks (VALETTE 
et al., 1998). Although phenolic compounds were not detected in the gall induced by $M$. javanica on the roots of soybean, Fonseca and Jaehn (2000) detected these compounds in galls induced by $M$. javanica on the roots of rubber trees.

The defence responses of hosts to nematodes include the hypersensitivity reaction (HR) and the activation of metabolic routes that lead to the production of many structural metabolites, including callose and lignin (FARIA et al., 2003; FAVERY et al., 2016; KINDTet al., 2016). In fact, there was an increase in cell lignification around the feeding site of the galling nematode in $G$. max, indicating an ineffective initial response. The proteinase inhibition and the consequent increase in total protein amount are also defence responses from the host plant (FARIA et al., 2003). However, the histochemical analysis did not detect the intense presence of protein in gall tissues. Such a result would imply that proteinases were not inhibited, which is compatible with the susceptibility degree of this cultivar. We noticed the presence of starch, which could aid with nematode nourishment and gall cell machinery maintenance, and of lipid droplets in the nematode tissues and others nearby. The nematode energy, which was accumulated during embryonic development, should be sufficient for juveniles to hatch and successfully parasitize the plant, indicating that the presence of lipid droplets in the nematode could be related to this fact. Infecting larvae do not feed until parasitism is established, and their energy reserve consists of lipid droplets stored in the posterior part of their bodies, which are sufficient for their maintenance for approximately two weeks (ABAD et al., 2003). According to Van Gundy et al. (1967), if J2 individuals spent over $50 \%$ of their body lipid reserves during the search for a host, they would not be able to infect the plant.

\section{Conclusions}

The root galls resulting from the interaction between Meloidogyne javanica and Glycine max presented varied sizes and shapes. This interaction resulted in the induction of a well-defined feeding site, formed by a group of differentiated cells close to the anterior region of the nematodes' bodies. This site was responsible for nourishing and supporting the nematodes' development until they reached the adult female stage. The differentiated cells also provoked the complete disorganisation of the vascular cylinder, which might have interfered with xylem and phloem transport. The giant cells were multinucleate, with a dense cytoplasm, numerous cytoplasmic organelles (mainly mitochondria), a fragmented vacuole and an invaginating wall. Lipid droplets were especially found in the nematode and may be involved in the parasitism process. Although reactive oxygen species (ROS) were detected in both gall and healthy tissue, its intense reaction in cell walls of galls can drive the mechanisms of cell hypertrophy, a common trait in gall development. Phenolic compounds and flavonoids usually detected during the plant response, were not seen in this study.

\section{Acknowledgments}

We would like to thank Laboratory of Anatomy, Plant Development and Interactions (LADEVI); Laboratory of Plant Physiology (LAFIVE), Post Graduate Program in Plant Biology and the Federal University of Uberlândia, and CNPq by the scholarship to D. C. Oliveira.

\section{References}

ABAD, P.; FAVERY,B.; ROSSO,M.N.;CASTAGNONESERENO, P. Root-knot nematode parasitism and host response: molecular basis of a sophisticated interaction. Molecular Plant Pathology, London, v. 4, n. 4, p. 217224, 2003. DOI: 10.1046/j.1364-3703.2003.00170.x

ABAD-FRANCH, F. MONTEIRO, J. O. N.; GURGELGONÇALVES. Ecology, evolution and the long-term surveillanceof vector-borne Chagas disease: a multiscale 477 appraisal of the tribe Rhodniini (Triatominae). Acta Tropica, Amsterdam, v. 110, n. 2-3, p. 159-177, 2009. DOI: 10.1016/j.actatropica.2008.06.005 
ALMEIDA ENGLER, J. de; VAN POUCKE, K.; KARIMI, M.; GROODT, R. de; GHEYSEN, G.; ENGLER, G.; GHEYSEN, G. Dynamic cytoskeleton rearrangements in giant cells and syncytia of nematodeinfected roots. The Plant Jounal: for Cell and Molecular Biology, Oxford, v. 38, n. 1, p. 12-26, 2004. DOI: 10.1111/j.1365-313X.2004.02019.x

ASMUS, G. L.; FERRAZ, L. C. C. B.; GLÓRIA, B. A. Alterações anatômicas em raízes de milho (Zea mays L.) parasitadas por Meloidogyne javanica. Nematropica, Auburn, v. 30, n. 1, p. 33-39, 2000.

BEDETTI, C. B.; MODOLO, L. V.; ISAIAS, R. M. S. The role of phenolics in the control of auxin in galls of Piptadenia gonoacantha (Mart.) MacBr (Fabaceae: Mimosoideae). Biochemical Systematics and Ecology, Richmond, v. 55, p. 53-59, 2014. DOI: 10.1016/j. bse.2014.02.016

BERG, R. H.; FESTER, T.; TAYLOR, C. G. Development of the root-knot nematode feeding cell. In: BERG, R. H.; TAYLOR, C. G. (Ed.). Plant cell monographs, cell biology of plant nematode parasitism. Springer, Berlim, Heidelberg, 2008. p. 115-152.

BIRD, A. F. The ultrastructure and histochemistry of a nematode-induced giant-cell. The Jounal Biophysical and Biochemical Cytology, Nova York, v. 11, n. 3, p. 701$715,1961$.

CARMO, D. B.; SANTOS, M. A. Hospedabilidade de plantas infestantes aos fitonematóides Meloidogyne javanica e Pratylenchus brachyurus. In: ENCONTRO INTERNO; SEMINÁRIO DE INICIAÇÃO CIENTÍFICA, 7., 12., 2008, Uberlândia. Anais... Uberlândia: Universidade Federal de Uberlândia, 2008. p. 1-9.

CASTRO, J. M. C.; SANTOS, C. A. F.; FLORI, J. E.; SIQUEIRA, S. V. C.; NOVAES, P. A. R.; LIMA, R. G. Reaction of Psidium accessions to the Meloidogyne enterolobii root-knot nematode. Acta Horticulturae, Leuven, v. 959, n. 5, p. 51-57, 2012. DOI: 10.17660/ ActaHortic.2012.959.5

COSTA, N. P.; MESQUITA, C. M.; MAURINA, A. C.; FRANÇA NETO, J. B.; KRZYZANOWSKI, F. C; HENNING, A. A. Qualidade fisiológica, física e sanitária de sementes de soja produzidas no Brasil. Revista Brasileira de Sementes, Londrina, v. 25, n. 1, p. 128-132, 2003

DAVIS, E. L.; HUSSEY, R. S.; BAUM, T. J. Getting to the roots of parasitism by nematodes. Trends in Parasitology, Londres, v. 20, n. 3, p. 134-141, 2004. DOI: $10.1016 /$ j.pt.2004.01.005

DEL RÍO, L. A.; PUPPO, A. Reactive oxigen species in plant signaling. Berlin, Heidelberg: Springer-Verlag, 2009. 245 p.

ENDO, B. Y. Histopathology and ultrastructure of crops invaded by certain sedentary endoparasitic nematodes. In: VEECH, J. A.; DICKSON, D. W. (Ed.). Vistas on nematology. Hyattsville: Society of Nematologists, 1987. p. 196-201.

FARIA, C. M. D. R.; SALGADO, S. M. L.; CAMPOS, H. D.; RESENDE, M. L. V.; CAMPOS, V. P.; COIMBRA, J. L. Mecanismos de ataque e defesa na interação nematoide-planta. In.: FERNANDES, J. M.; PRESTES, A. M.; PICININI, E. C. (Ed.). Revisão anual de patologia de plantas. Passo Fundo: RAPP, 2003, v. 11, cap. 11, p. 373-410.

FAVERY, B.; QUENTIN, M.; JAUBERT-POSSAMAI, S.; ABAD, P. Gall-forming root-knot nematodes hijack key plant cellular functions to induce multinucleate and hypertrophied feeding cells. Journal of Insect Physiology, Oxford, v. 84, n. 6, p. 60-69, 2016. DOI: 10.1016/j. jinsphys.2015.07.013

FEDER, N.; O'BRIEN, T. P. Plant microtechnique: some principles and new methods. American Journal of Botany, Baltimore, v. 55, n. 1, p. 123-142, 1968. DOI: 10.1002/j.1537-2197.1968.tb06952.x

FERRAZ, C. C. B.; MONTEIRO, A. R. Nematoides. In: BERGAMIN FILHO, A.; KIMATI, H.; AMORIM, L. (Ed.). Manual de fitopatologia: princípios e conceitos. 3. ed. São Paulo: Agronômica Ceres, 1995. v. 1, p. 168-201.

FERRAZ, L. C. C. B. As meloidoginoses da soja: passado, presente e futuro. In: SILVA, J. F. V. (Org.). Relações parasito-hospedeiro nas meloidoginoses da soja. Londrina: EMBRAPA Soja/Sociedade Brasileira de Nematologia, 2001. p. 15-38.

FERRAZ, L. C. C. B.; BROWN, D. J. F. Nematologia de plantas: fundamentos e importância. In: FERRAZ, L. C. C. B.; BROWN, D. J. F. (Org.). Interação plantanematoide: estratégias de alimentação. Manaus: Norma Editora, 2016. p. 82-84.

FINLEY, A. M. Histopathology of Meloidogyne chitwoodi on russet burbank potato. Journal of Nematology, Jay, v. 13, n. 4, p. 486-491, 1981.

FONSECA, H. S.; FERRAZ, L. C. C. B.; MACHADO, S. R. Caracterização do vacuoma de células gigantes induzidas por espécies de Meloidogyne em raízes de seringueira RRIM 600. Nematologia Brasileira, Campinas, v. 27, n. 2, p. 193-198, 2003.

FONSECA, H. S.; JAEHN, A. Estudos dos mecanismos de resistência em raízes de porta enxertos de seringueira inoculadas com M. javanica. Nematologia Brasileira, Campinas, v. 24, n. 2, p. 233-237, 2003. 
GALINA, F. A. Enzima regula geração de radicais livres durante a respiração celular. FAPERJ. Rio de Janeiro, 2006. Disponível em: http://www.faperj.br/?id=753.2.4. Acesso em: 21 fev. 2019.

GOLINOWSKI, W.; GRUNDLER, F. M. W.; SOBCZAK, M. Changes in the structure of Arabidopsis thaliana during female development of the plant-parasitic nematode Heterodera schachtii. Protoplasma, Viena, v. 194, n. 1-2, p. 103-116, 1996.

GUNNING, B. E. S. Transfer cells and their role in transport of soluts in plants. Science Progress, Oxford, v. 64, n. 256, p. 539-568, 1977.

HOFMANN, J.; BANORA, M. Y.; ALMEIDA ENGLER. J. de; GRUNDLER, F. M. W. The role of callose deposition along plasmodesmata in nematode feeding sites. Molecular Plant Microbe Interactions, St. Paul, v. 23, n. 5, p. 549-557, 2010. DOI: 10.1094/MPMI23-5-0549

HORI, K. Insect secretions and their effect on plant growth, with special reference to hemipterans. In: SHORTHOUSE, J. D.; ROHFRITSCH, O. (Ed.). Biology of insect-induced galls. New York: Oxford University Press, 1992. p. 157-170.

HUSSEY, R. S.; GRUNDLER, F. M. W. Nematode parasitism of plants. In: PERRY, R. N.; WRIGHT D. J.; (Ed.). The physiology and biochemistry of freeliving and plant-parasitic nematodes. New York: CABI International, 1998. p. 213-243.

HUSSEY, R. S.; JANSSEN, G. J. W. Root-knot nematodes: meloidogyne species. In: STARR, J. L.; COOK, R.; BRIDGE, J. (Ed.). Plant resistance to parasitic nematodes. Wallingford: CAB International, 2002. p. 43-70.

HUSSEY, R. S.; WILLIAMSON, V. M. Physiological and molecular aspects of nematode parasitism. In: BARKER, K. R.; PEDERSON, G. A.; IITA, G. L. Annual report and research highlights. Ibadan Internacional Institute of Tropical Agriculture, 1998. p. 56-57.

INOMOTO, M. M.; SILVA, R. A. Importância dos nematoides da soja e influência da sucessão de cultura. In: SIQUERI, F.; CAJU, J.; MOREIRA, M. (Ed.). Boletim de pesquisa de soja 2011. Rondonópolis: Fundação MT, 2011. p. 392-399.

JENSEN, W. A. Botanical histochemistry: principles and practice. San Francisco: WH Freeman, v. 140, n. 3567, 408 p. 1962.

JOHANSEN, D. A. Plant microtechnique. New York: McGraw- Hill, 1940. 523 p.

JONES, M. G. K. Host cell responses to endoparasities nematode attack. Structure and function of giant cells and syncytia. Annals of Applied Biology, Aberystwyth, v. 97, n. 3, p. 353-372, 1981. DOI: 10.1111/j.1744-7348.1981. tb05122.x

JONES, M. G. K.; DROPKIN, V. H. Scanning electron microscopy of nematode induced giant transfer cell. Cytobios, Cambridge, v. 5, n. 3, p. 149-161, 1976.

JONES, M. G. K.; GUNNING, B. E. S. Transfer cells and nematode induced giant cells in Helianthemum. Protoplasma, Viena, v. 87, n. 1-3, p. 273-279, 1976.

JONES, M. G. K.; NORTHCOTE, D. H. Nematodeinduced syncytium - a multinucleate transfer cell. Jounal of Cell Science, Cambridge, v. 10, n. 3, p. 789-809, 1972.

KARNOVSKY, M. J. A formaldehyde-glutaraldehyde fixative of high osmolality for use in electron microscopy. Journal of Cell Biology, Nova York, v. 27, n. 2, p. 137138, 1965.

KARSSEN, G.; MOENS, M. Root-knot nematodes. In: PERRY, R. N.; MOENS, M. (Ed.). Plant nematology. Wallingford: CAB International, 2006. p. 59-90.

KAWANO, T. Roles of reactive oxygen speciesgenerating peroxidase reactions in plant defense and growth induction. Plant Cell Reports, New York, v. 21, n. 9, p. 829-837, 2003.

KINDT, T.; GOVERSE, A.; HAEGEMAM, A.; WALMERDAM, S.; WANJAU, C.; JAHANI, M.; ENGLER, G.; de ALMEIDA ENGLER, J.; GHEYSEN, G. Redirection of auxin flow in Arabidopsis thaliana roots after infection by root-knot nematodes. Jounal of Experimental Botany, Lancaster, v. 67, n. 15, p. 45594570, 2016. DOI: 10.1093/jxb/erw230

KLESSIG, D. F.; DURNER, J.; NOAD, R.; NAVARRE, D. A.; WENDEHENNE, D.; KUMAR, D.; ZHOU, J. M.; SHAH, J.; ZHANG, S.; KACHROO, P.; TRIFA, Y.; PONTIER, D.; LAM, E.; SILVA, H. Nitric oxide and salicylic acid signaling in plant defence. Proceedings of the National Academy of Sciences, Washington, v. 97, $\mathrm{n}$. 16, p. 8849-8855, 2000. DOI: 10.1073/pnas.97.16.8849

KRUSBERG, L. R.; NIELSEN, L. W. Pathogenesis of root-knot nematodes to the Porto Rico variety of sweet potato. Phytopathology, St. Paul, v. 48, p. 30-39, 1958.

LISZKAY, A.; VAN DER ZALM, E.; SCHOPFER, P. Production of reactive oxygen species intermediates $\mathrm{O} 2 \bullet, \mathrm{H}_{2} \mathrm{O}_{2}$ and $\mathrm{OH} \bullet$ by maize roots and their role in wall loosening and elongation growth. Plant Physiology, Rockville, v. 136, n. 2, p. 3114-3123, 2004. DOI: 10.1104/ pp.104.044784

MAFFEI, M. E.; MITHÖFER, A.; BOLAND, W. Before gene expresssion: early events in plant-insect interaction. 
Trends in Plant Science, Londres, v. 12, n. 7, p. 310-315, 2007. DOI: $10.1016 /$ j.tplants.2007.06.001

MANI, M. S. Ecology of plant galls. The Hague: Dr. W. Junk Publ., 1964. 434 p.

MAZIA, D.; BREWER, P. A.; ALFERT, M. The cytochemistry staining and measurement of protein with mercuric bromophenol blue. Biological Bulletins, Chicago, v. 104, n. 34, p. 57-67, 1953.

O'BRIEN, T. P.; McCULLY, M. E. The study of plant structure principles and select methods. Melbourne: Termarcarphi Pty, 1981. 45 p.

OLIVEIRA, D. C.; MOREIRA, A. S. F. P.; ISAIAS, R. M. S. Functional gradients in insect gall tissues, studies on neotropical host plants. In: FERNANDES, G. W.; SANTOS, J. C. (Ed.). Neotropical insect galls. Springer Netherlands, Dordrecht, p. 35-49, 2014.

PEARSE, A. G. E. Histochemistry theoretical and applied: preparative and optical technology. $4^{\text {th }}$ ed. Edinburgh: Churchill Livingston, 1980. 439 p.

RAMAN, A. Insect-induced plant galls of India: unresolved questions. Current Science, Bangalore, v. 92, n. 6, p. 748-757, 2007.

REDDIGARI, S. R.; SUNDERMENN, C. A.; HUSSEY, R. S. Isolation of subcellular granules from secondstage juveniles of Meloidogyne incognita. Journal of Nematology, Byron, v. 17, n. 4, p. 482-488, 1985.

REHMAN, S.; GUPTA, V. K.; GOYAL, A. K. Identification and functional analysis of secreted effectors from phytoparasitic nematodes. BMC Microbiology, Londres, v. 16, p. 48, 2016. DOI: 10.1186/s12866-0160632-8

REYNOLDS, E. S. The use of lead citrate at high $\mathrm{pH}$ as an electron-opaque stain in electron microscopy. The Journal of Cell Biology, Nova York, v. 17, n. 1, p. 208212, 1963.

ROSSETTI, S.; BONATTI, P. M. In situ histochemical monitoring of ozone- and TMV-induced reactive oxygen species in tobacco leaves. Plant Physiology and Biochemistry, Bari, v. 39, n. 5, p. 433-442, 2001. DOI: 10.1016/S0981-9428(01)01250-5

SASS, J. E. Botanical microtechnique. $2^{\text {th }}$ ed. Ames: Iowa State College Press, 1951. 228 p.

SIDDIQUI, I. A.; TAYLOR, D. P. Histopathogenesis of galls induced by Meloidogyne naasi in wheat roots. Journal of Nematology, Jay, v. 2, n. 3, p. 239-247, 1970.

SOBCZAK, M.; GOLINOWSKI, W. Genomics and Molecular Genetics of Plant-Nematode Interactions. In: JONES, J.; FENOLL, C.; GHEYSEN, G. (Ed.). Cyst nematodes and syncytia, in genomics and molecular genetics of plant-nematode interactions. Dordrecht: Springer Science+Business Media B.V, 2011. p. 61-82.

TAYLOR, A. L.; SASSER, J. N. Biology, identification and control of root-knot nematodes (Meloidogyne sp.). Raleigh: North Carolina State University Graphics, 1978. $111 \mathrm{p}$.

TUITE, J. Plant pathological methods: fungi and bacteria. Minneapolis: Burgess Publishing Company, 1969. 239 p.

VALETTE, C.; ANDARY, C.; GEIGER, J. P.; SARAH, J. L.; NICOLE, M. Histochemical and cytochemical investigations of phenols in roots of banana infected by the Burrowing nematode Radopholus similis. Phytopathology, St. Paul, v. 88, n. 11, p. 1141-1148, 1998. DOI: 10.1094/PHYTO.1998.88.11.1141

VAN GUNDY, S. D.; BIRD, A. F.; WALLACE, H. R. Aging and starvation in juvenile of Meloidogyne javanica and Tylenchulus semipenetrans. Phytopathology, St. Paul, v. 57, n. 6, p. 559-571, 1967.

VIEIRA, P.; ENGLER, G.; ALMEIDA ENGLER, J. de. Whole-mount confocal imaging of nuclei in giant feeding-cells induced by root-knot nematodes in Arabidopsis. New Phytologist, Lancaster, v. 195, n. 2, p. 488-496, 2012. DOI: 10.1111/j.1469-8137.2012.04175.x

VIEIRA, P.; ESCUDERO, C.; RODIUC, N.; BORUC, J.; RUSSINOVA, E.; GLAB, N.; MOTA, M.; VEYLDER, L. de; ABAD, P.; ENGLER, G.; de ALMEIDA, E. J. Ectopic expression of Kip-related proteins restrains rootknot nematode-feeding site expansion. New Phytologist, Lancaster, v. 199, n. 2, p. 505-509, 2013. DOI: 10.1111/ nph. 12255

VOET, D.; VOET, J. G.; PRATT, C. W. Fundamentos de bioquímica. Porto Alegre: Artmed, 2002. 931 p.

WANDERLEY, M. J. A.; SANTOS, J. M. Resistance of sweet potato cultivars to Meloidogyne incognita. Fitopatologia Brasileira, Brasília, v. 29, n. 4, p. 437-440, 2004. DOI: $10.1590 / \mathrm{S} 0100-41582004000400014$

WESTERICH, J. N. Estudos histopatológicos e ciclos biológicos de Meloidogyne mayaguensis e M. javanica em tomateiros com gene Mi. 2010. Dissertação (Mestrado) Universidade Estadual Paulista, Faculdade de Ciências Agronômicas de Botucatu.

WESTERICH, J. N.; RODELLA, R. A.; ROSA, J. M. O.; WILCKEN, S. R. S. Alterações anatômicas induzidas por Meloidogyne enterolobii $(=\mathrm{M}$. mayaguensis $)$ e Meloidogyne javanica em tomateiros resistentes a meloidoginose. Summa Phytopathologica, Botucatu, v. 38, n. 3, p. 192-197, 2012.

WHITEHEAD, A. G. Plant nematode control. Wallingord: CAB International, 1997. 384 p. 
